\title{
Little Ice Age glaciers in the Balkans: low altitude glaciation enabled by cooler temperatures and local topoclimatic controls
}

\author{
P.D. Hughes \\ Geography, School of Environment and Development, Oxford Road, the University of Manchester M13 9PL, UK
}

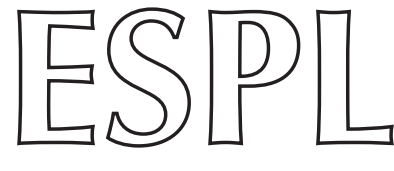

Earth Surface Processes and Landforms

ABSTRACT: Moraine ridges are present in the highest cirques of the Durmitor massif in Montenegro and post-date the widespread Pleistocene moraines of this area. Lichenometry suggests that at least eight glaciers were present in the 19th century and correlate with the culmination of the Little Ice Age in the European Alps. Cooler temperatures combined with local topoclimatic controls, including windblown and avalanching snow as well as shading, were crucial for the formation and survival of these glaciers below the regional equilibrium-line altitude. The resultant regional equilibrium line altitude (ELA) was positioned close to the highest peaks between 2400 and $2500 \mathrm{~m}$, with local controls such as avalanche, windblown snow and shading depressing the ELA in the northern cirques to 2130-2210 m. This ELA position was very low for this latitude and lower than for most glaciers in the European Alps at any time during the Holocene, and even equivalent to many Alpine glaciers during the Younger Dryas. Today, one glacier still survives in Montenegro, in a deep northeast-facing cirque characterized by the largest combined areas of potential avalanche and windblown snow. Copyright @ 2009 John Wiley \& Sons, Ltd.

KEYWORDS: Little Ice Age; palaeoclimate; glaciers; Durmitor; Montenegro

\section{Introduction}

Glaciers across Europe were significantly larger during the 'Little Ice Age', a period characterized by a cooler climate than today with mean annual air temperatures ca $1^{\circ} \mathrm{C}$ lower. Matthews and Briffa (2005) argue that the term 'Little Ice Age' represents two concepts, one glaciological and the other climatic. Little Ice Age climate is defined as a short time interval between 1570 and 1900 AD when Northern Hemisphere summer temperatures fell significantly below the AD 19611990 mean. However, Matthews and Briffa (2005) recognize that Little Ice Age glacierization was forced by increased precipitation in addition to lower temperatures and this period can be defined most precisely in the European Alps spanning the period 1300-1950 AD. Indeed, Clague et al. (2009) argued that while the 'Little Ice Age' remains a useful term it should be restricted to glacier activity and not used in a climatic context.

Most, though not all, glaciers in the European Alps and the Pyrenees reached their Little Ice Age maximum in the 18th and 19th centuries (Grove, 2004), with many Alpine glaciers reaching their maximum extension in a final AD 1850/1860 advance (Ivy-Ochs et al., 2009). During the 20th century many glaciers never reached the extent of the previous centuries and, although interrupted by occasional phases of advance, many central and southern European glaciers underwent overall retreat. In fact, many small glaciers and glaciers in marginal environments across the globe were rapidly disappearing by the beginning of the 21 st century (Meier et al., 2003).

The Mediterranean mountains are all characterized by climate conditions marginal to glacier formation and even small changes in climate therefore can be critical for glacier behaviour (Hughes and Woodward, 2009). This is illustrated at the Debeli Namet glacier in Montenegro, the size of which fluctuated dramatically between 2001 and 2007 in response to changes in summer temperature and winter precipitation (Hughes, 2008). Some Mediterranean glaciers disappeared in the 20th century, such as the Corral de Veleta glacier in the Sierra Nevada, Spain. In fact, most Mediterranean glaciers experienced significant overall retreat through the 20th century, with only a few minor readvances in some years (Messerli, 1967; McGregor et al., 1995; Gabrovec, 1998; D'Alessandro et al., 2001; Federici and Stefanini, 2001; Çiner, 2004; Chueca et al., 2005; Gonzalez-Trueba et al., 2008; Pecci et al., 2008). 
The Calderone glacier in the Italian Apennines is one of the most intensively studied glaciers in the Mediterranean mountains. The glacier retreated through the 20th century, and between 1916 and 1990 its volume is estimated to have been reduced by about $90 \%$ and its area by about $68 \%$ (Gellatly et al., 1994). In recent years the glaciers split into two portions and the remaining ice is rapidly shrinking (D'Alessandro et al., 2001; Pecci et al., 2008). A similar situation of rapid glacier retreat has also been reported further north in the Italian Alps (Mortara et al., 2008; Villa et al., 2008)

The 20th century fate of the Italian glaciers is paralleled at the Triglav glacier in Slovenia. This glacier covered an area of 40 ha in the 19th century (Sifrer, 1963) but had retreated to only 3 ha by 1995 (Gabrovec, 1998) By the first decade of the 21 st century the Triglav glacier had almost disappeared and covered just 0.7 ha $\left(0.007 \mathrm{~km}^{2}\right)$ in 2003 . However a brief revival occurred after successive winters of heavy snowfall, so that by 2005 the glacier covered an area of $1.1 \mathrm{ha}\left(0.01 \mathrm{~km}^{2}\right)$ (Triglav-Čekada, 2007).

The capricious nature of the Mediterranean glaciers poses the question: what was the response of these glaciers to cooler and possibly wetter climate conditions during the Little Ice Age, when glaciers across Europe were larger than they are today? In Montenegro there are no known historical accounts of glacier extent before the 20th century - and even for that century there are very few (Hughes, 2008). The extent of glaciers in the mountains of Montenegro will have an important bearing on the possibility of equivalent glaciers elsewhere in the mountains bordering the Mediterranean and will provide new insight into the Little Ice Age environments in an important climatic zone.

This paper examines evidence for glacier change over the past 150 years in the Durmitor massif in Montenegro (Figure 1). The Debeli Namet glacier is the only known glacier in Montenegro and has been the focus of studies by Djurović (1996; 1999), Vasiljević (1997), Kern et al. (2007) and Hughes $(2007 ; 2008)$. The paper has three main aims, these are to: (1) examine evidence for recent glaciers and perennial snow patches in the high cirques of the Durmitor massif, Montenegro; (2) examine the timing of moraine and pronival rampart building in these high cirques using lichenometry; (3) reconstruct the characteristics of the former glaciers and snow patches and assess the local topoclimatic controls contributing to their development.

\section{Study Areas}

The Durmitor area in northern Montenegro contains 18 peaks over $2000 \mathrm{~m}$, including Bobotov kuk $(2523 \mathrm{~m})$, the highest peak in Montenegro. The bedrock of this area consists of Jurassic and Triassic limestones. At Zabljak (1450 m) the mean annual precipitation is $1494 \mathrm{~mm}$ (Ćurić, 1996; Kern et al., 2007) with a mean annual temperature of $5 \cdot 1{ }^{\circ} \mathrm{C}$ (Table 1 ). The annual precipitation in the high mountain area is much higher and according to Bošković and Bajković (2004) the upper catchments of the Piva and Tara rivers, which drain the Durmitor area, receive annual precipitation of 2500-3000 mm. The area was extensively glaciated during the Pleistocene producing a spectacular network of arêtes and glacial lakes in the central mountain area and moraines on the piedmont (Marović and Marković, 1972; Cerović, 1986). Recent results of a U-series dating programme indicate that the last major valley glaciers of this area formed during the Late Pleistocene, although the oldest and most extensive glacial deposits are Middle Pleistocene in age (Hughes and Woodward, 2008).

\section{Methods}

\section{Geomorphology and lichenometry}

The mountains of Montenegro were explored over a period of 15 weeks between 2005 and 2008. All the highest mountain areas were visited, including the Durmitor massif, which contains the highest peak in Montenegro (Bobotov kuk $2523 \mathrm{~m}$ a.s.l.). The overall Quaternary sequence of glacial deposits in these mountains was subdivided using morpholithostratigraphy and U-series dating (Hughes and Woodward, unpublished data). Field mapping of the highest cirques - the focus of this paper - was undertaken in late summer and autumn, when snow cover was at its least.

Landforms were mapped onto 1:10 000 base maps. The dimensions of landforms such as sediment ridges and dolines within cirque basins were measured using an abney level and $50 \mathrm{~m}$ measuring tape. Clasts on the surface of sediment ridges were described using shape indices with descriptors ranging from very angular to well-rounded (see chart inside cover of Evans and Benn, 2004). The shape of 25 clasts were described on each ridge crest and were selected at random and included a range of clast sizes from pebbles to large boulders. This was done in order to differentiate between sediment landforms that have been produced as a result of active transport, such as subglacially under dynamic ice, or were formed as a result of passive transport, such as subaerially as over the surface of a static snow patch or as a result of a rock slope failure (cf Boulton, 1978).

The lichen, Aspicilia calcarea, was used to establish the age of moraine surfaces. The search areas were subdivided into sites $25 \mathrm{~m}$ long (aligned along moraine crests) and $10 \mathrm{~m}$ wide, following Matthews (2005). At least 30 of the largest lichens were measured on boulder-sized clasts on moraine crests, avoiding low-lying depressions potentially supporting prolonged snow-cover. The 30 measurements were taken from at least 10 separate boulders. The mean of the five largest lichen thalli in these samples (Matthews, 2005) was then compared with the lichen age-size growth curve of Aspicilia calcarea established for the Durmitor region (Figure 2) (Hughes, 2007). This same procedure was also undertaken on Pleistocene moraines down-valley of the highest cirque moraines in order to establish the maximum lichen size achieved in the area.

\section{Glacier-climate reconstruction}

Former glacier limits were reconstructed based on the geomorphological evidence of former glacier occupation. The lower margins of the former glaciers and snow patches are well-constrained based on the position of frontal moraines or pronival ramparts. Lateral margins of former glaciers were constrained using lateral moraines and also trimlines that separate smoother, polished, bedrock covered inside the limits of the most recent former glacier and less smooth, polished, bedrock outside. The degree of surface weathering was also a factor in limiting the extent of former recent glaciers. Inside of trimline limits no, or very thin, regolith was present in grikes and doline depressions in contrast with outside of trimline limits where up to $2 \mathrm{~m}$ of unconsolidated regolith is widespread in similar situations.

Glacier surface area, equilibrium-line altitude (ELA) and length were calculated using the geomorphological data. The upper headwall limit of ice was estimated by extrapolating ice surface slopes deduced from trimlines and lateral moraines to a point on the backwall cliff. Former ice surfaces were then contoured by extrapolating from the points at the former ice 


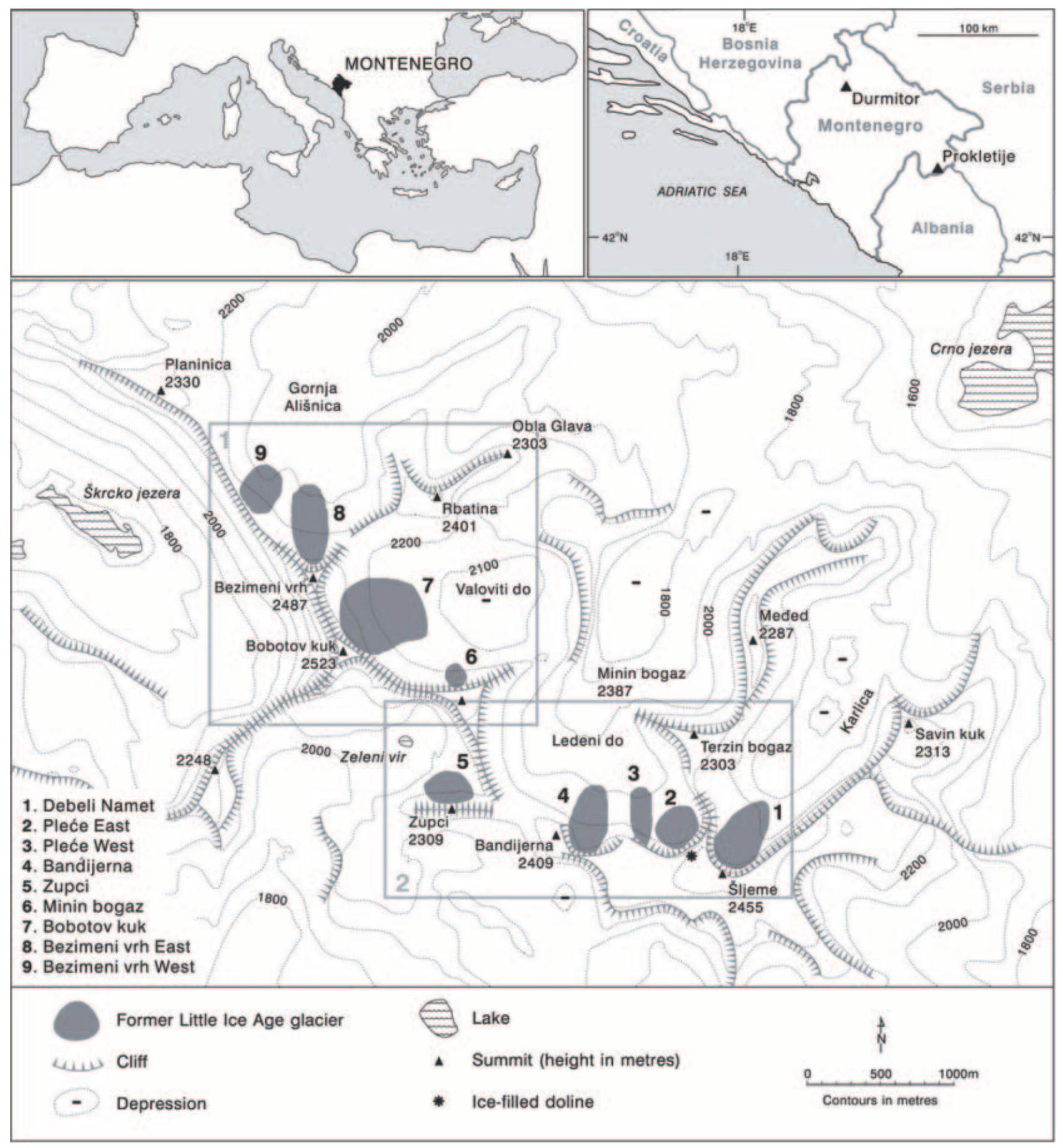

Figure 1. Locations of the highest cirque moraines and associated glacier limits in the Durmitor massif, Montenegro.

Table 1. Mean monthly temperature data $\left({ }^{\circ} \mathrm{C}\right)$ for Zabljak at an altitude of $1450 \mathrm{~m}$. Mean annual precipitation is $1494 \mathrm{~mm}$ (Ćurić, 1996 ; Kern et al., 2007). The period of observation is unknown

\begin{tabular}{|c|c|c|c|c|c|c|c|c|c|c|c|c|}
\hline J & $\mathrm{F}$ & M & A & M & $J$ & $J$ & A & $S$ & $\mathrm{O}$ & $\mathrm{N}$ & $\mathrm{D}$ & Mean annual temperature \\
\hline$-4 \cdot 8$ & $-3 \cdot 6$ & $-1 \cdot 2$ & $3 \cdot 8$ & 8.9 & 12.4 & 14.1 & 14.2 & $10 \cdot 4$ & $6 \cdot 2$ & $2 \cdot 4$ & -1.7 & $5 \cdot 1$ \\
\hline
\end{tabular}

margins with concave ice contours in the upper ice surface, convex over the lower surface and straight in the centre of the former glacier.

The median elevation of the glaciers (Braithwaite and Müller, 1980) was used to estimate the ELA of the former Durmitor cirque glaciers. Braithwaite and Raper (2007) found that there was strong correlation between observed ELA and median elevation median glacier elevation on 144 glaciers around the world. The median elevation divides the glacier surface into two equal parts and reflects the statistical median of the glacier surface area-altitude distribution. This is not the same as the median elevation of glaciers as described in 


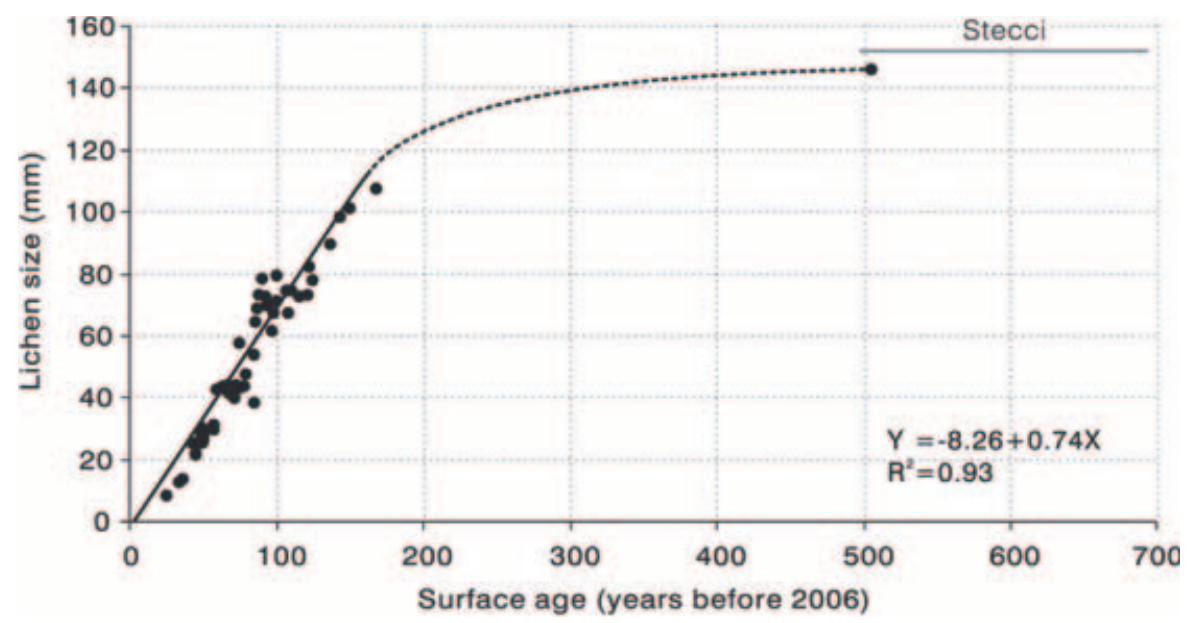

Figure 2. Lichen growth curve based on lichen measurements on gravestones and monuments in the Durmitor massif. On medieval stecci (tombstones) on the Zabljak plateau, at Grčko groblje $(1430 \mathrm{~m})$, the mean of the five largest lichens was $146.1 \mathrm{~mm}$ and this data was used to constrain the upper limits of the lichen growth curve. Adapted from Hughes (2007).

Meierding (1982) and Benn and Lehmkuhl (2000) in which a toe-to-headwall-ratio is used to obtain the so-called 'median' elevation. On very small glaciers with little altitudinal variation, such as these small former cirque glaciers in Montenegro, it could be argued that whichever method is applied to estimate the ELA the range of values is trivial. In fact, very small glaciers such as these frequently experience inter-annual negative or positive mass balance over the entire glacier surface (Hughes, 2008) and defining the position of the ELA year on year is theoretically problematic.

A simple degree-day model was used to calculate the amount of accumulation required to sustain the former Durmitor cirque glaciers. The mean annual temperature of $5 \cdot 1^{\circ} \mathrm{C}$ at Zabljak $(1450 \mathrm{~m})$ was extrapolated to different altitudes, including the ELAs of the former Durmitor glaciers, using a lapse rate of $0 \cdot 6^{\circ} \mathrm{C}$ per $100 \mathrm{~m}$. These annual temperatures were then distributed over a sine curve to provide daily temperature means using the following equation (from Brugger, 2006):

$$
T_{d}=A_{y} \sin (2 \pi d / \lambda-\Phi)+T_{a}
$$

where $T_{d}$ is the mean daily air temperature, $A_{y}$ is the amplitude of the yearly temperature (half of the annual temperature range. The annual mean monthly temperature range at Zabljak is $19 \cdot 0^{\circ} \mathrm{C}$ - see Table 1$), d$ is the day of the year ( 1 to 365$), \lambda$ is the period (365 days), $\Phi$ is the phase angle (taken as 1.93 radians to reflect the fact that January is the coolest month), and $T_{a}$ is the mean annual air temperature.

The annual accumulation required at the different altitudes to balance melting equals the sum of daily snow melt, using a degree-day factor. Braithwaite (2008) found that degree-day factors for snow on 66 glaciers worldwide had averages of $3.5 \pm 1.4$ and $4.6 \pm 1.4 \mathrm{~mm} \mathrm{day}^{-1} \mathrm{~K}^{-1}$ in low- and highaccumulation conditions, respectively, with an overall mean of $4.1 \pm 1.5 \mathrm{~mm}_{\text {day }}{ }^{-1} \mathrm{~K}^{-1}$, in accordance with earlier values reported in the literature (Braithwaite et al., 2006). Thus, a degree-day factor of $4.1 \mathrm{~mm}$ day $^{-1} \mathrm{~K}^{-1}$ was used in the simple degree-day model.

The potential contribution of both windblown and avalanching snow was examined using methods adapted from Sissons and Sutherland (1976). The potential contribution of windblown snow was calculated by taking the ratio between the drainage area leading directly onto the former glacier and snow patch surfaces $(D)$ and the total area of these former glacier and snow patch surfaces $(A)$. This provides only a crude estimate of the contribution of windblown snow since it does not take into account the up-hill transfer of snow, and also, it does not take into account the effects of prevailing wind direction. The influence of avalanche on accumulation was isolated using a separate avalanche ratio. This is the ratio between the total area susceptible to avalanche $(V)$, which is defined here as the ratio between the total area of slopes $>30^{\circ}$ leading directly onto the accumulation area of the glacier, and the total glacier area $(A)$. The contour spacing of slopes $>30^{\circ}$ was calculated for the 1:50 000 base maps and areas where contours exceeded this spacing were bounded and the total area calculated. This was achieved using layers in Photoshop and shape areas, for windblown snow and avalanche catchments, were calculated using ImageJ (Image Processing and Analysis in Java).

\section{Results and Interpretation}

Glacial geomorphological maps of the highest cirques are shown in Figure 3. In the Karlica valley (Figure 4), the highest moraines are situated in front of a modern glacier at Debeli Namet, and these moraines appear to have formed from the 19th century to the present-day (Hughes, 2007). A Pleistocene age for moraines below the Debeli Namet glacier has been established using U-series dating (Hughes and Woodward, 2008) (Figure 4). Apart from the Debeli Namet glacier in the Karlica valley, no other remaining glaciers were found in the Durmitor massif. However, multiple boulder ridges in four other cirques on Durmitor appear to correlate with the Debeli Namet moraines. These were identified in the below northfacing cliffs in the cirques of: Ledeni do; Valoviti do; Gornja Ališnica; and Zupci (Figures 1 and 3).

\section{Geomorphology and lichenometry - description}

Karlica - Debeli Namet

A modern glacier is present at the head of the Karlica valley in a north-east facing cirque below the steep cliffs of Šljeme (2455 m) and the geomorphology of the site is described in Hughes (2007). The glacier is situated between 2000 and $2200 \mathrm{~m}$ altitude and covered an area of ca $5 \mathrm{~h}$ in September 2006 (Figure 5). Three clear moraine ridge crests are present 


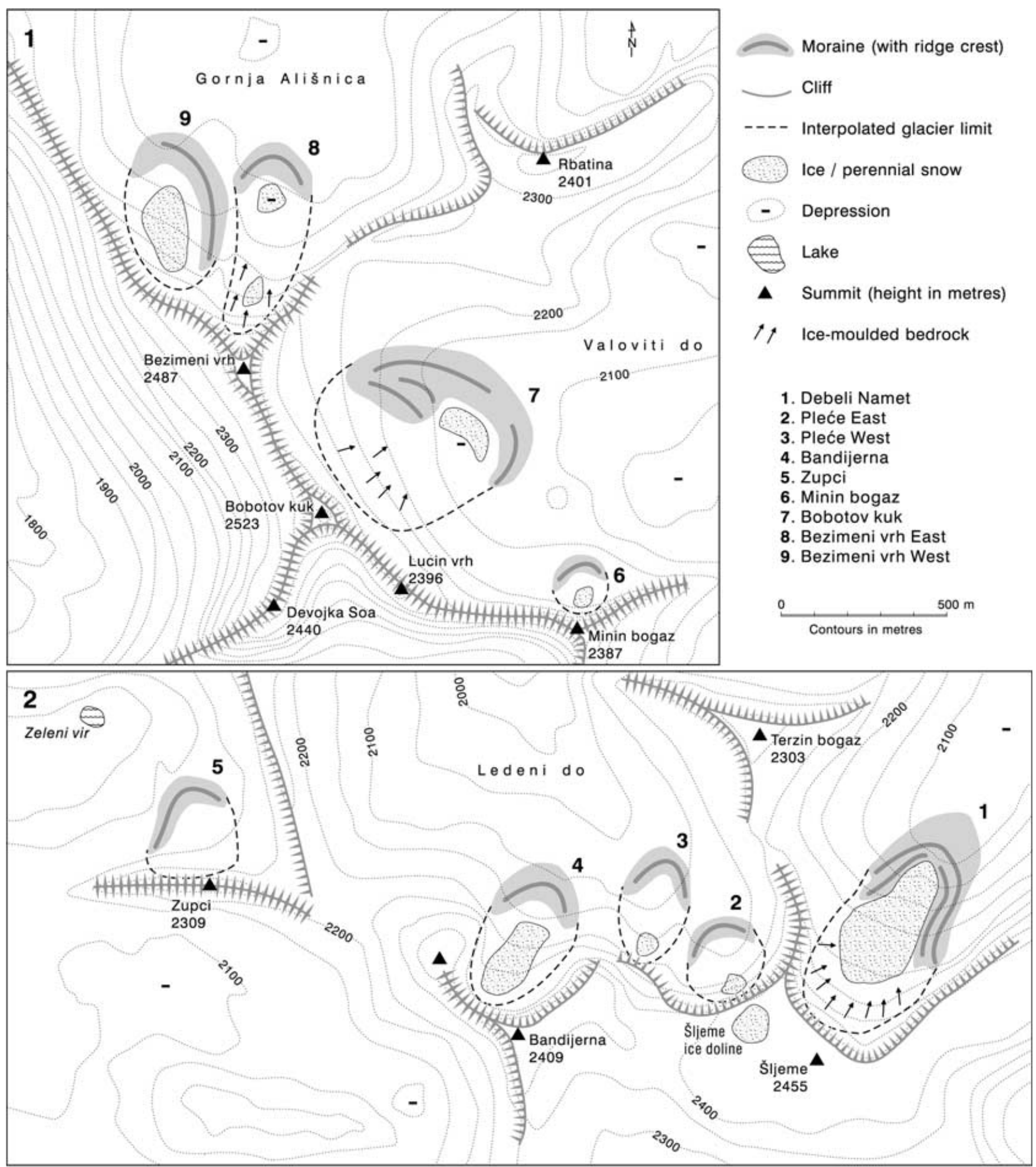

Figure 3. Glacial geomorphological maps of the highest Durmitor cirques.

in front of this glacier. Hughes (2007) used lichenometry to determine the surface age of these moraines and found that the two outer moraines had mean lichen sizes of $86.8 \mathrm{~mm}$ and $67.5 \mathrm{~mm}$, suggesting that the moraines were formed by a more extensive glacier at ca AD 1878 and 1904. Around $1 \mathrm{~km}$ down-valley of this small glacier, just above the Struğa pass between the peaks of Međed (2287 m a.s.l.) and Savin kuk (2313 $\mathrm{m}$ a.s.l.), there are clear end moraines (Figure 4). The mean of the five largest lichens on these moraines is $137.4 \mathrm{~mm}$. Secondary calcites cementing these moraines have recently been dated using $\mathrm{U}$-series to $10605 \pm 193\left({ }^{230} \mathrm{Th} /{ }^{232} \mathrm{Th}=99 \cdot 3\right)$ and $9575 \pm 836\left({ }^{230} \mathrm{Th} /{ }^{232} \mathrm{Th}=49.9\right)$ years (Hughes and Woodward, 2008) (Figure 4).

Ledeni do

Pleće

Two arcuate ridges, composed largely of subrounded (40\%) and subangular $(40 \%)$ boulders, are present in the cirque below the ridge of Pleće on Šljeme in the eastern head of the Ledeni do valley. The name of this valley, Ledeni do, translates as 'icy cold valley' in English and reflects the prolonged survival of winter snow in this valley shadowed by the northern 


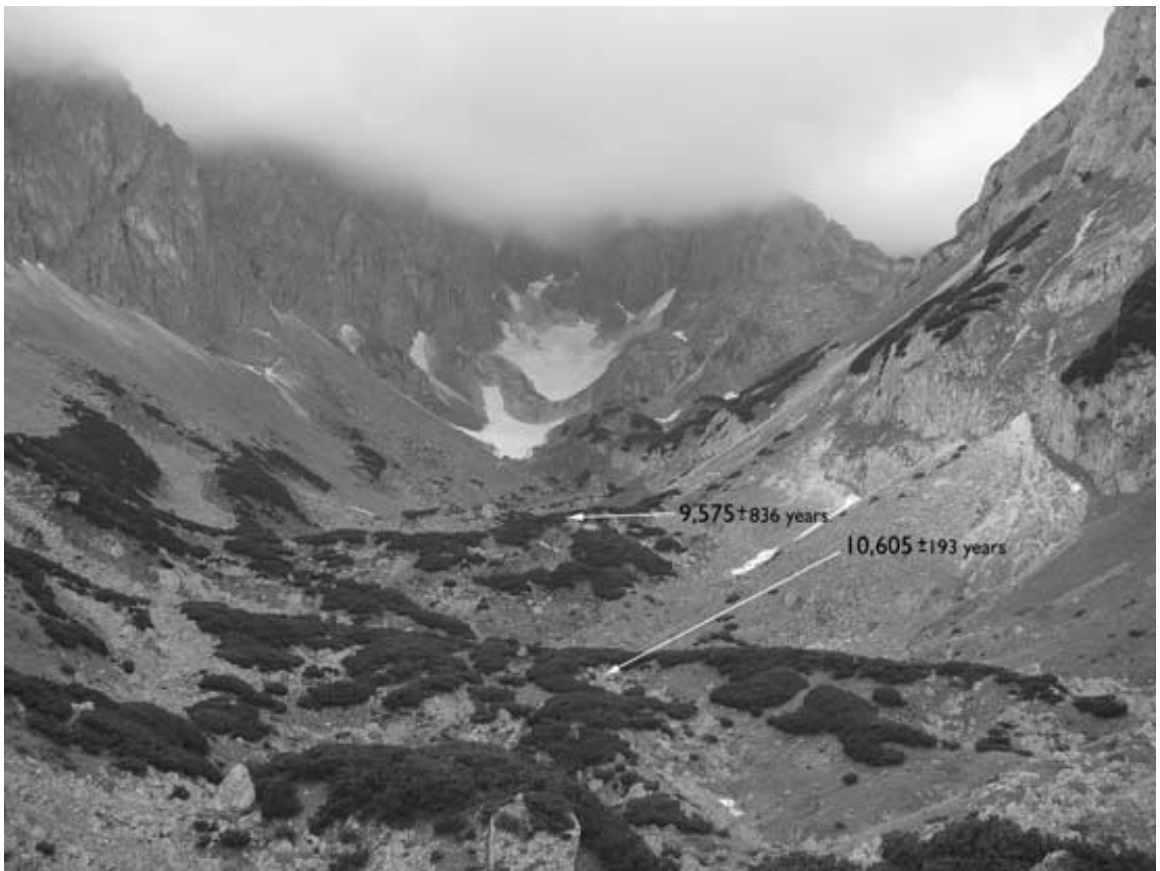

Figure 4. Photograph showing moraines in the Karlica Valley in the Durmitor Massif, Montenegro. Secondary calcites within these moraines have been dated using $\mathrm{U}$-series and provide a minimum age for the host moraines. These dates are significant because they demonstrate that the valley moraines are likely to be Late Pleistocene in age - possibly correlating with the Younger Dryas (from Hughes and Woodward, 2008). A modern glacier - the Debeli Namet - is present at the head of the valley and is bounded by three closely separated moraines (Hughes, 2007).

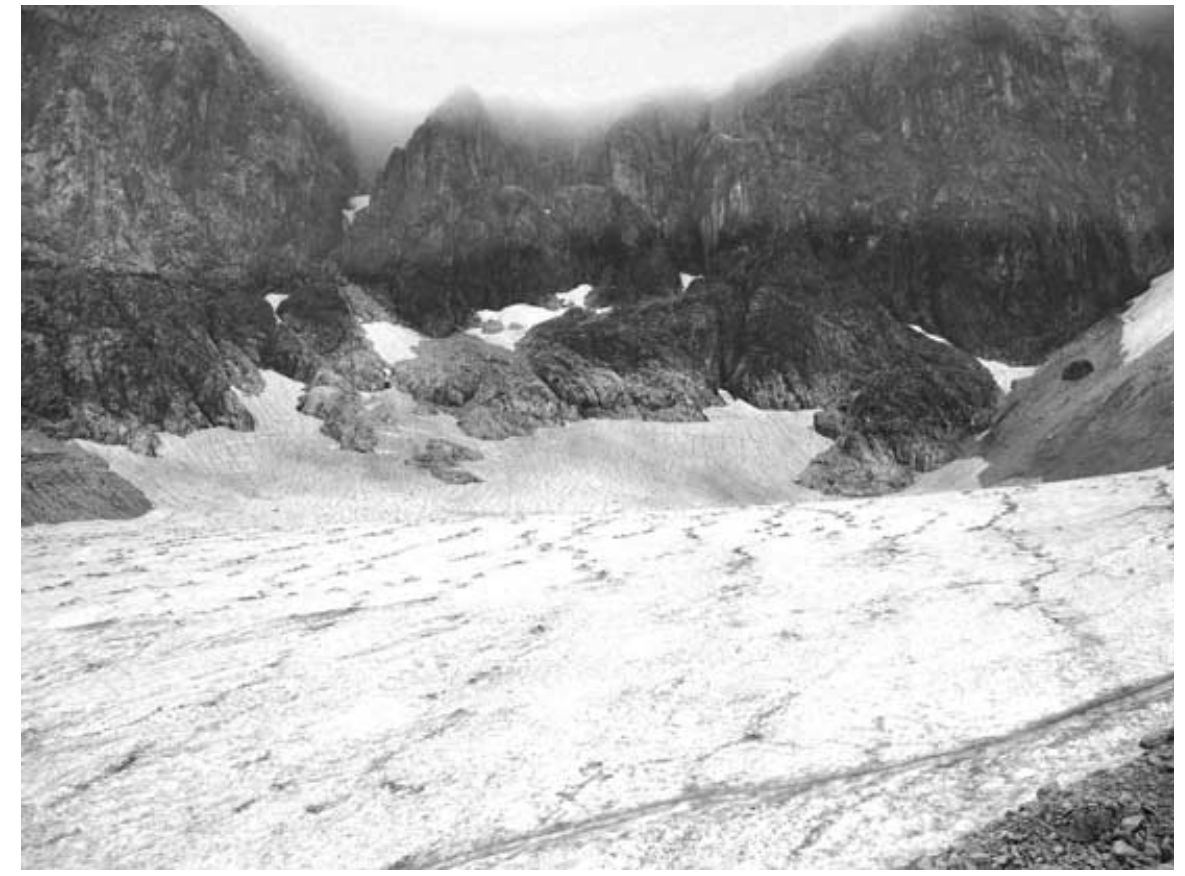

Figure 5. The Debeli Namet glacier. Photographed in September 2006.

cliffs of Šljeme and Bandijerna. The two boulder ridges are situated at an altitude of $2100-2150 \mathrm{~m}$. The western ridge is the lowest and the crest is situated $100 \mathrm{~m}$ from the base of the talus foot. The eastern ridge bounds the distal edge of a doline depression and is ca $200 \mathrm{~m}$ horizontal distance from the cliff face. The doline is filled with debris, and numerous smaller dolines are superimposed in the debris surface. Snow patches were present at the base of the cliffs above both these debris ridges in September 2007. The means of the five largest lichens on the crests of the western and eastern boulder ridges were 88.8 and $91.3 \mathrm{~mm}$, respectively. The mean of the five largest lichens on boulders down-valley of this ridge in the Ledeni do valley was $130 \cdot 6 \mathrm{~mm}$.

\section{Bandijerna}

Again in the Ledeni do, ca $1 \mathrm{~km}$ to the west of the Pleće sites described above and below the col between the peaks of Bandijerna (2409 m) and Milošev tok (2426 m), an apparently 'permanent' snow field was observed in October 2007 and September 2008 at an altitude of 2150 to 2250 m. In September 
2008, the snow field was reduced in size compared with the previous year and a $10 \mathrm{~m}$ wide zone of boulders surrounding the snow field appeared bleached, with no lichens present. A clear arcuate boulder ridge is present, situated ca $100 \mathrm{~m}$ distance in front of the snowfield margin in September 2008. The boulders are predominantly subrounded $(50 \%)$ and subangular $(30 \%)$ and several display striae. The mean of the five largest lichens on the boulder ridge crest was $83.3 \mathrm{~mm}$. As noted for the Pleće boulder ridges, the mean of the five largest lichens on boulders down-valley of this ridge in the Ledeni do valley was $130 \cdot 6 \mathrm{~mm}$.

Upper valoviti do

Minin bogaz

A snow patch was present in September 2008 below the north face of Minin bogaz $(2387 \mathrm{~m})$ draining into the upper basin of Valoviti do. An arcuate ridge of subangular (50\%) and angular (30\%) boulders was present ca $50 \mathrm{~m}$ in front of this snow patch. No lichens were measured at this locality.

\section{Bobotov kuk}

A broad ridge, composed of subrounded (40\%) and subangular $(40 \%)$ boulders, encloses small dolines below the northeast face of Bobotov kuk in the upper basin of Valoviti do at ca $2120 \mathrm{~m}$ (Figure 6). Ice was present in the base of these dolines in October 2005, September 2006 and September 2008 (no data from 2007). The moraine ridge crest is ca $400 \mathrm{~m}$ from base of the cirque backwall. The distal edge of the boulder ridge is situated on the lip of a small rock step separating this upper cirque from the lower and larger boulder-filled depression of Valoviti do. A 15 m wide zone of boulders surrounding the firn fields appeared bleached with no lichens present. On the crest of the boulder ridge the mean of the five largest lichens was $85.3 \mathrm{~mm}$. In contrast, the largest lichens on boulders in the lower doline of Valoviti do had an average size of $134.5 \mathrm{~mm}$.

\section{Gornja Ališnica - Bezimeni vrh}

Two neighbouring ridges of boulders are present below the north-facing cliffs of Bezimeni vrh. The eastern boulder ridge is the lowest at an altitude of ca $2120 \mathrm{~m}$ and is largely composed of subrounded (45\%) and subangular (35\%) boulders. The ridge crest is situated $150 \mathrm{~m}$ from the base of a steep talus slope leading to the pass of Veliki Struga $(2274 \mathrm{~m})$. The basin enclosed by the boulder ridge sometimes remains snowcovered throughout the year, as does the talus slope up-valley (observed in September 2008). The western ridge is situated at a higher elevation and is an arcuate ridge of largely subrounded (40\%) amd subangular (40\%) boulders that encloses a basin with a distance of ca $150 \mathrm{~m}$ between the ridge crest and the base of the cliff backwall (Figure 7). The means of the five largest lichens on boulders protruding from the eastern and western boulder ridges were 97.8 and $99.5 \mathrm{~mm}$, respectively. Immediately down-valley of these two boulder ridges, large boulders fill the valley floor. These support lichens with thalli up to $144 \mathrm{~mm}$ in diameter with a mean of the five largest lichens at $142.3 \mathrm{~mm}$.

\section{Zupci}

A clear arcuate ridge is present in the cirque below the northern cliffs of Zupci (Figure 8). The ridge crest is separated from the base of the backwall talus by a doline ca $150 \mathrm{~m}$ wide. The lower parts of this backwall talus is comprised of some extremely large boulders (>30 m diameter) (Figure 8). The arcuate ridge is vegetated by grass with large predominantly subrounded (45\%) and subangular (35\%) boulders present on the ridge surface. The mean of the five largest lichens on the boulders on this ridge was $102.9 \mathrm{~mm}$. The mean of the five largest lichens on boulders down-valley of this ridge, near the lake Zeleni vir, was $138.6 \mathrm{~mm}$.

\section{Other features of note}

Permanent snow and ice is also present in non-cirque locations. For example, snow and ice was present in a doline on the summit plateau of Šljeme in September 2008. The doline is $30 \mathrm{~m}$ deep and is filled by snow and ice $17 \mathrm{~m}$ in diameter (Figure 9). Permanent ice and snow is also present in several caves in the Durmitor massif. The most impressive and accessible is the ice cave known as Ledina Pecina on Obla Glava (2303 m) (Figure 1).

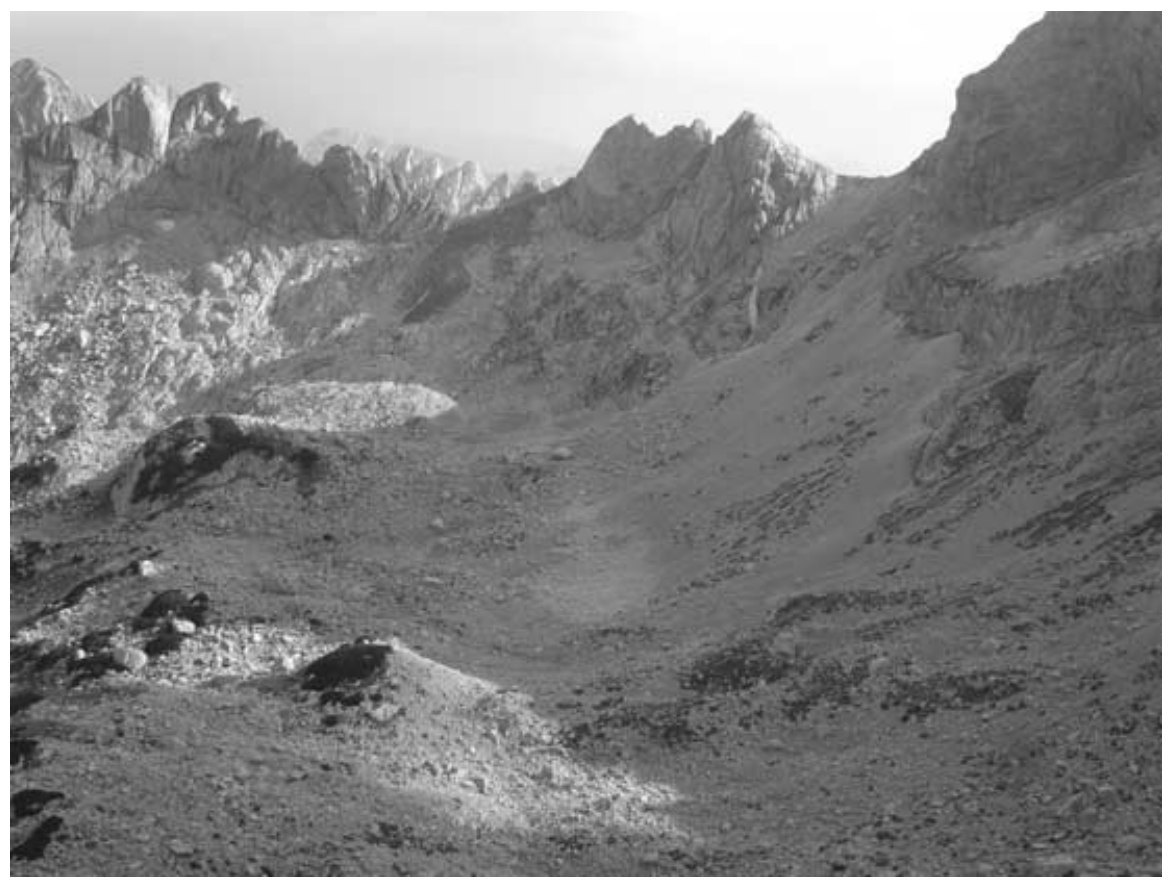

Figure 6. The uppermost cirque moraines of Valoviti do below the north-eastern face of Bobotov kuk (2523 m). The lighter stained area inside of these moraines was formed of a mixture of ice and debris. Photograph taken in September 2008. 


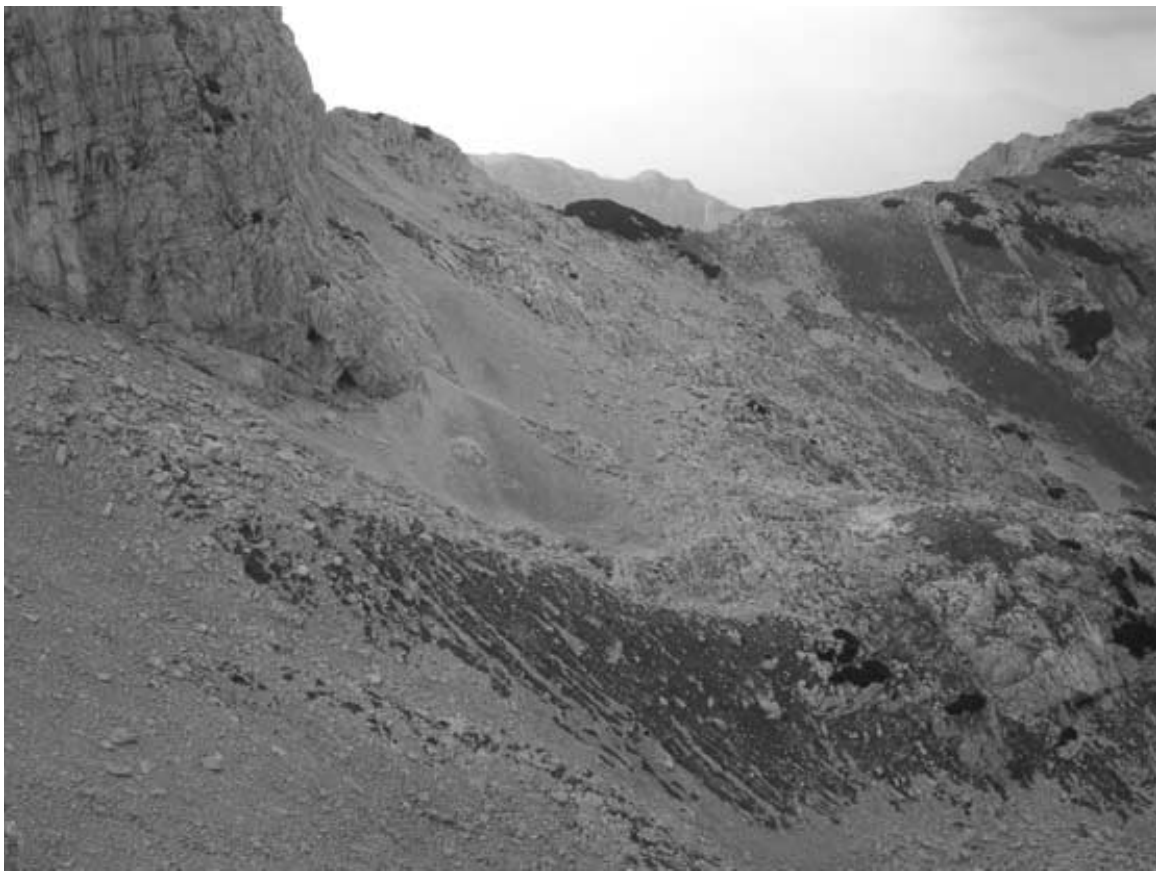

Figure 7. Arcuate moraine ridge below the north face of Bezimeni vrh (Bezimeni vrh West). Photograph taken in September 2008.

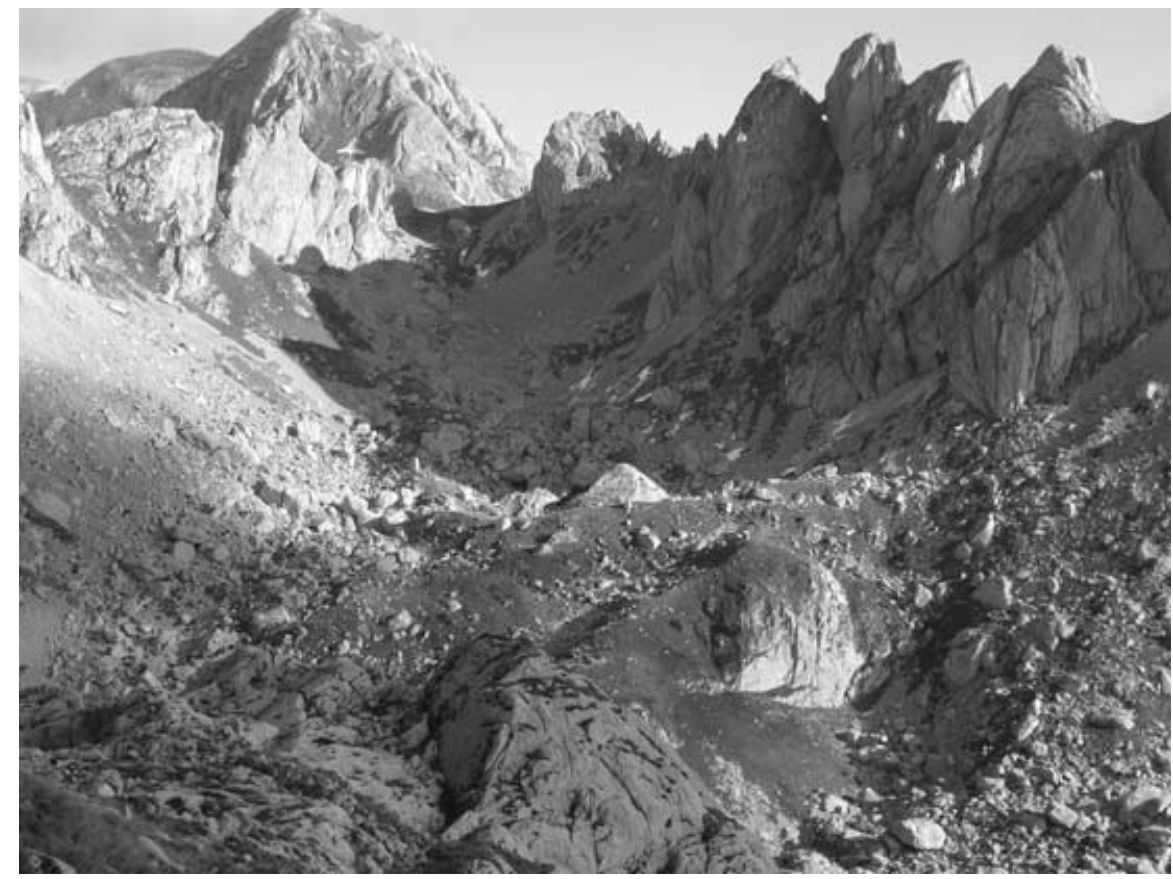

Figure 8. The Zupci moraines. Photograph taken in October 2005.

\section{Geomorphology and \\ lichenometry - intepretation}

All of the five cirques described above have boulder ridges present in their uppermost parts below steep backwall cliffs. The substantial proportion of subrounded and sometimes striated boulders suggests a subglacial origin for eight of the nine ridges (only the Minin bogaz ridge is interpreted as a pronival rampart). Moreover, eight of the nine boulder ridges are at least $100 \mathrm{~m}$ horizontal distance from the base of the cirque backwall and usually bounded the distal edge of doline basins. This suggests formation by dynamic ice rather than a static perennial snowfield, since the distance between the boulder ridge and the base of the cirque backwall is well beyond the threshold of 30-70 m, below which only protalus ramparts can form (Ballantyne and Benn, 1994). However, the presence of numerous subangular boulders in these ridges does suggest that these features are 'protalus moraines' whose form is 'influenced by moving ice, yet which continue to receive a supply of debris by direct gravitational transport across the ice surface' (Ballantyne and Benn, 1994). The only ridge dominated by angular boulders and situated less than $100 \mathrm{~m}$ from the base of the backwall was the Minin bogaz boulder ridge and this feature may be best interpreted as a pronival rampart.

The lichen-age growth curve established for the Durmitor area (Figure 2) can be used to determine the ages of different moraine surfaces in the Durmitor cirques based on the lichens size data decribed above. The strength of the regression 


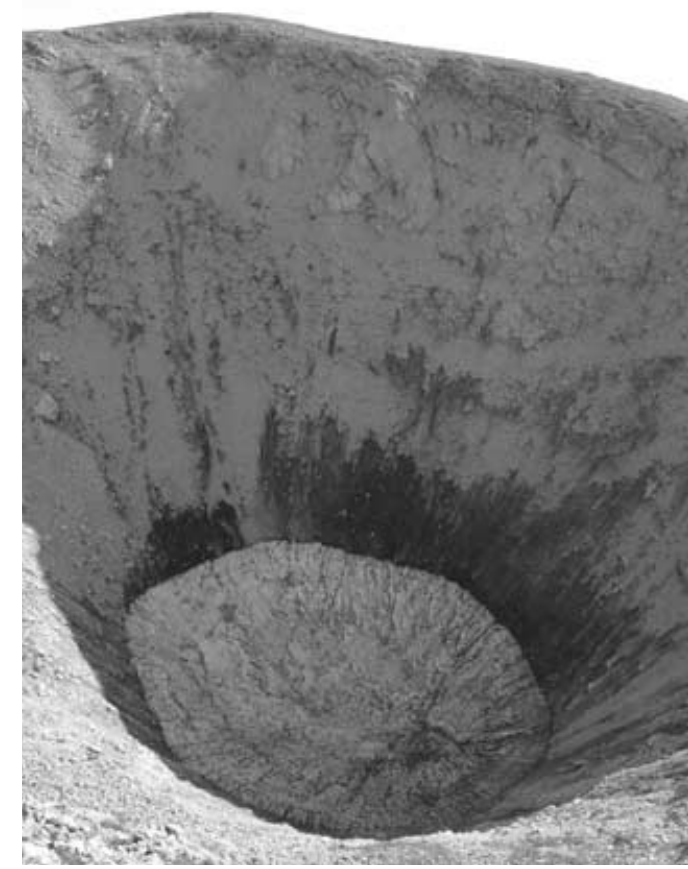

Figure 9. The ice-filled doline on the summit plateau of Šljeme. The ice surface has a diameter of $17 \mathrm{~m}$ and is situated in a doline that is $30 \mathrm{~m}$ deep. Photograph taken in September 2008. between the mean of the five largest lichen thalli and surface age (Figure 2) suggests that statistically, 92\% of the variance in the diameter of the largest lichens, from a total sample size of 30, can be attributed to variance in surface age.

No lichens are present on a moraine close to the margins of the modern Debeli Namet glacier. This suggests that the moraine was formed very recently (stratigraphical unit 4.1 in Table 2). Below the most recent Debeli Namet moraines, two additional separate moraine crests have lichen diameters consistent with a late 19th century (AD 1878) and an early 20th century age (AD 1904) (units $2 \cdot 1$ and $3 \cdot 1$ in Table 2). The mean percentage error between observed lichen size and the lichen size predicted using the regression is $11 \%$ (Hughes, 2007). The mean of the five largest lichen sizes on these two moraine crests differ by $19.3 \mathrm{~cm}$, which is much greater than the mean percentage error $(67.5 \pm 7.4 \mathrm{~cm}$ and $86.8 \pm 9.5 \mathrm{~cm})$, supporting interpretations that these moraines crests are significantly different in age. Moraines down-valley of the modern glacier and 19th century moraines at Debeli Namet have been shown to be Late Pleistocene in age, based on U-series dating (Hughes and Woodward, 2008; see description of Debeli Namet above). The mean of the five largest lichens on these moraines is $137.4 \mathrm{~mm}$ (unit 1.1 in Table 2). On equivalent moraines in neighbouring cirques and valleys the largest lichens are in the range $130 \cdot 6$ to $142.3 \mathrm{~mm}$ (means of five largest). This is close to the maximum thalli diameter observed for Aspicilia calcarea on the Zabljak plateau, at

Table 2. Lichenometry results from five different cirque-valley systems in the Durmitor massif. The stratigraphical units are order numerically in bold from $\mathbf{1 . 1}$ (oldest) to successively higher numbers representing younger moraine units. Where multiple moraine units of the same age are present in any cirque then these units are subdivided numerically in non-bold font, e.g. 2·1, 2·2, 2·3

Site

$(1 \cdot 1),(2 \cdot 1)$ : stratigraphical order

Karlica (1.1)

Karlica - Debeli Namet (2.1)

Karlica - Debeli Namet (3.1)

Karlica - Debeli Namet (4.1)

Ledeni do (1·1)

Ledeni do - Pleće East (2.1)

Ledeni do - Pleće West (2.2)

Ledeni do - Bandijerna (2.3)

Valoviti do (1/1)

Valoviti do - Bobotov kuk (2.1)

Valoviti do - Minin bogaz (2.2)

Gornja Ališnica (1·1)

Gornja Ališnica - Bezimeni vrh East (2·1)

Gornja Ališnica - Bezimeni vrh West (2.2)

Zupci (1·1)
Mean thalli diameter $(\mathrm{mm})$

of five largest lichens

Estimated surface age

Altitude (m)

$137 \cdot 4$

$86 \cdot 8$

67.5

2045

2050

2050

No lichens

$130 \cdot 6$

2130

$88 \cdot 8$

$91 \cdot 3$

$83 \cdot 3$

$134 \cdot 5$

$85 \cdot 3$

No data

$142 \cdot 3$

$97 \cdot 8$

$99 \cdot 5$

2050

$138 \cdot 6$
Beyond reliable growth range for lichenometry using Aspicilia calcarea. U-series ages of 9.6 and $10.6 \mathrm{ka}$ indicate a Late Pleistocene age for the moraines (Hughes and Woodward 2008). 1878

1904

Modern glacier present

Beyond reliable growth range for lichenometry using Aspicilia calcarea. Correlated with Late Pleistocene moraines below Debeli Namet.

1877

1872

1884

Beyond reliable growth range for lichenometry using Aspicilia calcarea. Correlated with Late Pleistocene moraines in the Karlica valley below Debeli Namet.

1881

No data

Beyond reliable growth range for lichenometry using Aspicilia calcarea. Correlated with Late Pleistocene moraines in the Karlica valley below Debeli Namet.

1864

1862

Beyond reliable growth range for lichenometry using Aspicilia calcarea. Correlated with Late Pleistocene moraines in the Karlica valley below Debeli Namet. 1857 
Grčko groblje $(1430 \mathrm{~m})$, where the mean of the five largest lichens on medieval stecci (tombstones) was $146.1 \mathrm{~mm}$ (Hughes, 2007). The lower values on the cirque and valley moraines probably reflect the higher altitude of these sites.

In all of the other Durmitor cirques, lichens are present on the highest moraines, unlike the highest moraines near the Debeli Namet glacier. The mean of the five largest lichens on the three separate moraines in the highest cirques of the Ledeni do valley ranged between $83.3 \pm 9.2$ and $91 \cdot 3 \pm 10 \cdot 0 \mathrm{~cm}$, corresponding to ages of between AD 1884 and 1872. The overlapping error on the lichen size-age predictions used to estimate these ages suggests that the moraine surfaces are similar in age and formed when glaciers were present simultaneously. These moraines correspond to moraines below the Debeli Namet described above that have been dated using lichens to ca AD 1878. The next set of moraines down-valley support much larger lichens (mean of the five largest $=130.6 \mathrm{~cm}$ ) that are close to the maximum observed by Aspicilia calcarea in this area and are similar in size to those on moraines dated to the Late Pleistocene in the neighbouring Karlica valley. Thus, these moraines are interpreted as Late Pleistocene in age too.

In the Valoviti do cirque, the mean of the five largest lichens on the Bobotov kuk moraines suggests of $85.3 \mathrm{~cm}$ corresponds with an estimated surface date of AD 1881. This is very similar to the age of the neighbouring Ledeni do and Debeli Namet moraines (stratigraphical units Ledeni do 2.1, 2.2, 2.3 and Karlica 2.1 in Table 2). Although no lichen measurements were taken from the Minin bogaz pronival rampart, it is likely that this feature formed at the same time as the Bobotov kuk moraines. The mean of the five largest boulders on the dense moraines in the lower Valoviti do was $134.5 \mathrm{~cm}$, which is similar to the situation on Late Pleistocene moraines in other cirques nearby (see above) and a similar age is interpreted for these moraines too.

\section{Glacier-climate reconstruction results}

The evidence described above suggests that there is evidence for eight glaciers and at least one perennial snow patch in the Durmitor cirques dating from the 19th century. The characteristics of these former features are presented in Table 3. The mean ELA was ca $2170 \mathrm{~m}$ although individual glacier ELAs were in the range $2130-2210 \mathrm{~m}$. The glaciers were small and covered a total area of only $0.75 \mathrm{~km}^{2}$. The largest glacier was situated in the upper part of Valoviti do below the highest peak of the massif, Bobotov kuk and had a total area of $0.32 \mathrm{~km}^{2}$ (Table 3).

The modern mean annual temperature at the summit of the highest Durmitor peak of Bobotov kuk $(2523 \mathrm{~m})$ is estimated at $-1.4^{\circ} \mathrm{C}$ based on extrapolations from Zabljak (Table 1), using a lapse rate of $0.6^{\circ} \mathrm{C}$ per $100 \mathrm{~m}$ altitude. The degree-day model predicts that around $3500 \mathrm{~mm}$ w.e. of snow accumulation is required to offset annual melt. At the lower ELAs of the former cirque glaciers (2130-2210 m), the degree-day model predicts that $5000 \mathrm{~mm}$ of snow accumulation is required to offset annual melt.

Assuming a depression of mean annual temperature of $1{ }^{\circ} \mathrm{C}$ for the Little Ice Age (Grove, 2004), then a mean annual temperature of $-2 \cdot 4^{\circ} \mathrm{C}$ at the summit of Bobotov kuk (2523 m) corresponds to annual melt of $2900 \mathrm{~mm}$ using the degree-day model described above. Under a $1^{\circ} \mathrm{C}$ depression of mean annual temperature at the ELAs of the former cirque glaciers (2130-2210 m), the degree-day model predicts that $4250 \mathrm{~mm}$ of snow accumulation would have been required to offset annual melt.

The combined snow-blow and avalanche ratios $(D / A)$ for the eight former glaciers and snow patch ranged from 0.5 to 2.4 while avalanche ratios $(V / A)$ ranged from 0.2 to 1.75 (Table 3).

Table 3. Characteristics of the 19 th century Durmitor glaciers. $D / A$ ratio $=$ combined snow blow and avalanche ratio. $V / A$ ratio $=$ avalanche ratio (see text for details). ELA = equilibrium line altitude

\begin{tabular}{|c|c|c|c|c|c|c|}
\hline Site & $\begin{array}{c}\text { Glacier surface } \\
\text { area }\left(\mathrm{km}^{2}\right)\end{array}$ & $\mathrm{ELA}(\mathrm{m})$ & Length (m) & Orientation & $D / A$ ratio & V/A ratio \\
\hline $\begin{array}{l}\text { 1. Debeli Namet } \\
\text { (19th century) }\end{array}$ & $0 \cdot 11$ & 2130 & 595 & $035^{\circ} \mathrm{NE}$ & $2 \cdot 4$ & 1.75 \\
\hline $\begin{array}{l}\text { 2. Pleće East } \\
\text { (19th century) }\end{array}$ & 0.06 & 2150 & 305 & $335^{\circ} \mathrm{NW}$ & $1 \cdot 4$ & 0.4 \\
\hline $\begin{array}{l}\text { 3. Pleće West } \\
\text { (19th century) }\end{array}$ & 0.02 & 2125 & 360 & $000^{\circ} \mathrm{N}$ & 0.9 & $0 \cdot 2$ \\
\hline $\begin{array}{l}\text { 4. Bandijerna } \\
\text { (19th century) }\end{array}$ & 0.05 & 2200 & 390 & $025^{\circ} \mathrm{NE}$ & 0.9 & $0 \cdot 8$ \\
\hline $\begin{array}{l}\text { 5. Zupci } \\
\text { (19th century) }\end{array}$ & $0 \cdot 05$ & 2150 & 275 & $340^{\circ} \mathrm{NW}$ & $0 \cdot 8$ & $0 \cdot 8$ \\
\hline $\begin{array}{l}\text { 6. Minin bogaz } \\
\text { (19th century) }\end{array}$ & $0 \cdot 01$ & 2200 & 175 & $350^{\circ} \mathrm{NW}$ & 0.5 & 0.5 \\
\hline $\begin{array}{l}\text { 7. Bobotov kuk } \\
\text { (19th century) }\end{array}$ & $0 \cdot 32$ & 2210 & 685 & $055^{\circ} \mathrm{E}$ & 0.9 & 0.6 \\
\hline $\begin{array}{l}\text { 8. Bezimeni vrh East } \\
\text { (19th century) }\end{array}$ & 0.08 & 2190 & 500 & $005^{\circ} \mathrm{NE}$ & $1 \cdot 1$ & $1 \cdot 1$ \\
\hline \multirow{2}{*}{$\begin{array}{l}\text { 9. Bezimeni vrh West } \\
\text { (19th century) }\end{array}$} & $0 \cdot 05$ & 2180 & 330 & $055^{\circ} \mathrm{NE}$ & 0.9 & 0.9 \\
\hline & $\begin{array}{l}\text { Total area } \\
\text { (19th century): } 0.75\end{array}$ & $\begin{array}{l}\text { Overall mean } \\
\text { (19th century): } 2170\end{array}$ & & & & \\
\hline
\end{tabular}

\footnotetext{
1 Snow patch.
} 


\section{Discussion}

The late 19th century age of the highest cirque moraines in the Durmitor massif corresponds with the culmination of the Little Ice Age in Europe (Matthews and Briffa, 2005). In the Alps, the Little Ice Age glacier maximum occurred during the AD 1850/1860 advance (Ivy-Ochs et al., 2009) similar to the range of estimated glacier advance in Montenegro (AD 1857-1884). However, the Durmitor moraines appear to postdate the most extensive phase of Little Ice Age glaciation elsewhere in southern Europe. For example, in the Pyrenees, Maritime Alps and Italian Appenines, the maximum Little Ice Age extent occurred during the late 18th century AD (D'Orefice et al., 2000; Federici and Stefanini, 2001; Nesje and Dahl, 2000, p. 141; Grove, 2004, p. 218). However, the late 19th century was characterized by a period of colder summers in the eastern Mediterranean (Repapis and Philandras, 1988) and increased precipitation in the southern Balkans (Katsoulis and Kambetzidis, 1989), compared with 20th century averages.

A second phase of re-advance is also represented in one of Durmitor cirques - at the Debeli Namet site, where a glacier still survives today. Lichenometry suggests that this phase of readvance dates from ca AD 1904 (Hughes, 2007) (Table 2). The absence of equivalent moraines recording glacier advance in other cirques suggests that ice had disappeared from these cirques by this time. Little is known about the behaviour of the Debeli Namet glacier after this period of readvance, although the glacier was advancing building a small frontal moraine in 2005 before retreating dramatically during the very hot summer of 2007 (Hughes, 2008).

During the late 20th century at Debeli Namet glacier (modern ELA: $2150 \mathrm{~m}$ ), Hughes (2008) calculated that $5094 \mathrm{~mm}$ w.e. of accumulation was required to balance melting - increasing to more than $6000 \mathrm{~mm}$ w.e. during the 2003-2007 period. A significant proportion of this accumulation is likely to be supplied by avalanche since these values of accumulation are twice that of the estimated annual precipitation estimated for the high mountain region, and more than three times the measured mean annual precipitation value at Zabljak. However, it is possible that temperatures are and were lower than that suggested when assuming a uniform lapse rate $\left(0.6^{\circ} \mathrm{C} / 100 \mathrm{~m}\right)$ and these values of accumulation may be upper estimates. This is because all of the former glaciers were all north or north-east facing and are likely to have been favoured by shading. Nevertheless, high values of accumulation may be explained by local accumulative inputs, such as from windblown snow and avalanching. In future, energy balance modelling utilizing local topoclimatic data may help test the results of the degree-day model applied here - especially in testing the suitability of the chosen the degree-day factor.

The potential contribution of avalanching and windblown snow to glacier mass balance is indicated in the D/A and V/A ratios (Table 3 ). The highest $D / A$ was for the Debeli Namet and indicates that the potential area contributing windblown and avalanching snow was 2.4 times the size of the late 19th century glacier. Only two other glaciers had a D/A ratio greater than 1: the former Pleće East and Bezimeni vrh East glaciers. All the other former glaciers and the Minin bogaz snowpatch had ice and snow surfaces that were larger than the areas potentially contributing windblown and avalanching snow to these surfaces. The Debeli Namet also had by far the largest avalanche ratio $(V / A)$. At most sites, the potential area of avalanche input the to the former glacier and snowpatch surfaces was close in size to the overall drainage area onto the glacier, reflecting the steep terrain characteristic of the Durmitor massif. The smallest D/A and V/A values, indicating limited potential contribution of windblown and avalanching snow, are associated with the Minin bogaz site, which may explain why this site appears to have only supported a snowpatch during the Little Ice Age.

The Little Ice Age ELA of the only remaining glacier, the Debeli Namet, differed very little from the present-day ELA. However, at $2130 \mathrm{~m}$, the former ELA was the lowest of all the former Little Ice Age glaciers in the Durmitor massif. The fact that a glacier has survived into the 21 st century at only one site suggests that the other cirques of Durmitor are more sensitive to climate changes than the Debeli Namet glacier. It is possible that the large supply of snow accumulation from avalanche to the Debeli Namet glacier insulates this site from pertubations in regional climate (Hughes, 2008). Indeed the $D / A$ and V/A ratios, reflecting the potential contribution of windblown and avalanching snow to glacier mass balance, for the former Little Ice Age glacier at this site were the much higher than the former Durmitor glaciers (Table 3).

Higher air temperatures since the Little Ice Age appear to have caused the disappearance of other Durmitor glaciers, a situation in common with mountain regions in many parts of the world. Reductions in snow accumulation are unlikely to have been a major factor leading to glacier retreat. This is because, as noted above, the Debeli Namet glacier still survives today as a result of very high accumulation sourced from a combination of direct precipitation, avalanche and windblown snow. Local controls on glacier survival such as avalanche, and indeed shading, are less effective in other Durmitor cirques compared with the Debeli Namet glacier, hence the absence of glaciers in these cirques today. Nevertheless, such local controls are still likely to have been important for glacier survival during the Little Ice Age because even then, the regional snow line would have only been positioned close the highest peaks (see below).

Under the late 20th century climate (Table 1), ca $3500 \mathrm{~mm}$ of snow accumulation is required to balance annual melting at the summit altitude of Bobotov kuk (2523 m) - the highest summit in this area and wider Montenegro. This value of snow accumulation is above the range of precipitation values (2500-3000 mm) known for the headwaters of rivers in this area (Bošković and Bajković, 2004) and explains why the regional ELA, and the perennial snowline, is well above the highest summits of Durmitor. Based on a $1^{\circ} \mathrm{C}$ depression of mean annual temperature, the snow accumulation required to offset melting at the summit of Bobotov kuk is lowered to ca $2900 \mathrm{~mm}$. Thus, assuming this value of temperature depression occurred during the 19th century like elsewhere in Europe (Grove, 2004), then it is probable that the regional ELA was positioned close to the highest Durmitor peaks between 2400 and $2500 \mathrm{~m}$, with local controls such as avalanche, windblown snow and shading depressing the ELA in the northern cirques to 2130-2210 m (Table 3). This is lower than many of the Little Ice Age glaciers in the European Alps at any time during the Holocene and equivalent to some Alpine glaciers during the Younger Dryas ( $c f$ Federici et al., 2008; Ivy-Ochs et al., 2009). For example, in the Maritime Alps the ELA of the Piano del Praiet glacier during the Younger Dryas was between 2380 and $2390 \mathrm{~m}$ (Federici et al., 2008).

Local controls on snow accumulation are not restricted to cirques. Karstic topography, in the form of dolines and caves, provides opportunities for the build-up of thick snow accumulations leading to permanent ice, such as at Ledina Pecina ice cave and the Šljeme ice doline (Figure 9). These observations are important because they suggest that karstic terrain may promote the survival of perennial snow and ice at altitudes that are much lower than if the complex karstic topography were not there. This mechanism was suggested for differences 
in Pleistocene glacier development between limestone and ophiolite terrains in northern Greece (Hughes et al., 2007).

The Little Ice Age moraines on Durmitor are only 150-200 m higher than nearby Late Pleistocene moraines (Figure 4) and a similar difference existed between the ELAs of these glaciers (Hughes and Woodward, unpublished data). However, because of the small size of the Little Ice Age glaciers, the source areas of avalanching and windblown snow would have been much larger relative to the size of the glacier surface compared with the Late Pleistocene glaciers. Thus, Pleistocene glacier ELAs would have been closer to the regional ELA than the Little Ice Age glaciers. The latter would have been sustained by accumulation sourced predominantly from avalanche and windblown snow, while the former would have been more reliant on direct precipitation onto the glacier surface. This has implications when comparing the climatic significance of the recent Holocene and much older Pleistocene glaciers as it would be misleading to suggest that a depression of the Late Pleistocene ELAs by only 100-150 m reflects only a small change in summer temperature or precipitation.

Interestingly, the largest Little Ice Age glacier was situated in the upper part of Valoviti do below Bobotov kuk, the highest peak of Durmitor. No glacier is present today and the only glacier remaining on Durmitor is the Debeli Namet glacier in the Karlica cirque below the peak of Šljeme. However, during the Little Ice Age this glacier was smaller than the Valoviti do glacier. This suggests that the Debeli Namet Namet glacier was (and is still) less sensitive to regional climate change than the Valoviti do glacier. The cirque at the latter site is much larger than the Karlica cirque, which hosts the Debeli Namet glacier (Figure 1). Consequently, Valoviti do is less favoured by shading and avalanche and thus, any regional rise in temperatures or reduction in precipitation is likely to have a greater impact on glacier mass balance at this site than at the Debeli Namet site.

The evidence of many more Little Ice Age glaciers than currently exists in the Durmitor massif has implications for mountain areas elsewhere in the Balkans. Moraines suspected to have formed during the Little Ice Age have been recognized in the Prokletije Mountains of Albania, in front of currently active glaciers (Milivojević et al., 2008; Hughes, in press). Small glaciers have also been reported further east in Bulgaria (Grunewald et al. 2006) and, not only is it is likely that these glaciers were significantly larger during the Little Ice Age, it is also likely that many more glaciers were present across the Balkan mountains. In northern Greece, Hughes et al. (2006) recognized moraines in the high cirques of Smolikas and attributed these to the Younger Dryas (12.9 -11.5 ka), while on Mount Olympus, Smith et al. (1997) tentatively considered similar moraines to be of 'Neoglacial age'. On Smolikas the last glaciers had ELAs of $2425 \mathrm{~m}$ - close to altitudes of the Little Ice Age glaciers on Durmitor. However, climate data from the Smolikas area suggests that the current glacier ELA is situated close to $3000 \mathrm{~m}$ and a major depression of summer temperature is required to form glaciers in this area - even when combined with very high values of precipitation (Hughes et al., 2006, p. 54). Thus it is improbable that Holocene glaciers formed anywhere in Greece, unlike further north in the Balkans where numerous glaciers were present as late as the Little Ice Age and with some remaining today.

\section{Conclusions}

At least eight cirque glaciers were present in the Durmitor massif, Montenegro, during the 19th century, closely correlat- ing with the maximum extent of Little Ice Age glaciers in the European Alps. The Durmitor glaciers were exceptionally low for this latitude and had ELAs that were as low as some Alpine glaciers during the Younger Dryas. The regional ELA during the $19^{\text {th }}$ century in this area of Montenegro was ca 2400$2500 \mathrm{~m}$, while in shaded northern cirques prone to avalanching and accumulation of wind blown snow this was lowered to $2130-2210 \mathrm{~m}$, which was sufficient to sustain small cirque glaciers. By the turn of the 20th century ice had disappeared from seven of these cirques, leaving a glacier present only at one site-Debeli Namet. This glacier appears to have advanced in the first decade of the 20th century and was still present at the turn of the 21 st century.

Acknowledgements - This research was funded by a Peter Fleming Award from the Royal Geographical Society (with IBG). I would like to thank Graham Bowden for redrawing all of the illustrations.

\section{References}

Ballantyne CK, Benn DI. 1994. Glaciological constraints on protalus rampart development. Permafrost and Periglacial Processes 5: 145-53.

Benn DI, Lehmkuhl F. 2000. Mass balance and equilibrium-line altitudes of glaciers in high-mountain environments. Quaternary International 65/66: 15-29.

Bošković M, Bajković I. 2004. Waters of Montenegro. BALWOIS: Water Observation and Information System for Balkan Countries. Paper number: A-403. 9 pp. Available at: http://balwois.mpl. ird.fr/balwois/administration/full_paper/ffp-870.pdf [accessed 5 December 2008]

Boulton GS. 1978. Boulder shapes and grain-size distributions of debris as indicators of transport paths through a glacier and till genesis. Sedimentology 25: 773-799.

Braithwaite RJ. 2008. Temperature and precipitation climate at the equilibrium-line altitude of glaciers expressed by the degree-day factor for melting snow. Journal of Glaciology 54: 437-444.

Braithwaite RJ, Müller F. 1980. On the parameterization of glacier equilibrium line altitude. IAHS-AISH Publication 126; 263-271.

Braithwaite RJ, Raper SCB, Chutko K. 2006. Accumulation at the equilibrium line altitude of glaciers inferred from a degree-day model and tested against field observations. Annals of Glaciology 43: 329-334.

Braithwaite RJ, Raper SCB. 2007. Glaciological conditions in seven contrasting regions estimated with the degree-day model. Annals of Glaciology 46: 296-302.

Brugger KA. 2006. Late Pleistocene climate inferred from the reconstruction of the Taylor River glacier complex, southern Sawatch Range, Colorado. Geomorphology 75: 318-329.

Cerović B. 1986. Durmitor and the Tara Canyon. Durmitor National Park: Belgrade.

Chueca J, Julián A, Saz-Sánchez MA, Creus-Novau J, López-Moreno J. 2005. Responses to climatic changes since the Little Ice Age on Maladeta Glacier (Central Pyrenees). Geomorphology 68: 167-182.

Çiner A. 2004. Turkish glaciers and glacial deposits. In Quaternary Glaciations - Extent and Chronology. Part I: Europe, Ehlers J, Gibbard PL (eds). Elsevier: Amsterdam; 419-429.

Clague JJ, Menounos B, Osborn G, Luckman BH, Koch J. 2009. Nomenclature and resolution in Holocene glacial chronologies. Quaternary Science Reviews. 28: 2231-2238 doi:10.1016/j. quascirev.2008.11.016

Ǵurić M. 1996. Climate of Durmitor national park. In The Nature of National Park Durmitor, Lješević M (ed). Faculty of Geographie, University of Belgrade Special Editions, Volume 8; 151-162.

Djurović P. 1996. Visokoplaninski kras Durmitora - geomorfoloska studija. Doktorska disertacija, Geografski fakultet. PhD thesis (in Serbian), Beograd.

Djurović P. 1999. Natural and anthropogenic influences as threats to pits in the Debeli namet glacier (Durmitor National park, 
Montenegro). In Contribucion del estudio cientifico de las cavidades karsticas al conocimiento geologico, Andreo B, Carrasco F, Durán JJ (eds).Patronato da la Cueva de Nerja, Instituto de Investigacion, Malaga; 579-585.

D'Alessandro L, Orefice MD, Pecci M, Smiraglia C, Ventura R. 2001. The strong reduction phase of the Calderone glacier durino the last two centuries: reconstruction of the variation and of the possibile scenarios with GIS technologies. In Global Change and Protected Areas, Visconti G, et al. (eds). Kluwer Academic Publishers; 425-433.

D'Orefice M, Pecci M, Smiraglia C, Ventura R. 2000. Retreat of Mediterranean glaciers since the Little Ice Age: case study of Ghiacciaio del Calderone, Central Apennines, Italy. Arctic, Antarctic and Alpine Research 32: 197-201.

Evans DJA, Benn DI. 2004. A Practical Guide to the Study of Glacial Sediments. Arnold: London.

Federici PR, Stefanini MC. 2001. Evidences and chronology of the Little Ice Age in the Argentera Massif (Italian Maritime Alps). Zeitschrift für Gletscherkunde und Glazialgeologie 37: 35-48.

Federici PR, Granger DE, Pappalardo M, Ribolini A, Spagnolo M, Cyr A.J. 2008. Exposure age dating and Equilibrium Line Altitude reconstruction of an Egesen moraine in the Maritime Alps, Italy. Boreas 37: 245-253.

Gabrovec M. 1998. The Triglav glacier between 1986 and 1998. Geografski zbornik 38: 89-110.

Gellatly AF, Smiraglia C, Grove JM, Latham R. 1994. Recent variations of Ghiacciaio del Calderone, Abruzzi, Italy. Journal of Glaciology 40: 486-490.

González Trueba JJ, Martín Moreno R, Martínez de Pisón E, Serrano E. 2008. Little Ice Age' glaciation and current glaciers in the Iberian Peninsula. The Holocene 18: 551-568.

Grove J. 2004. Little Ice Ages: Ancient and Modern. Volumes I and II. Routledge: London.

Grunewald K, Weber C, Scheithauer J, Haubold F. 2006. Mikrogletscher im Piringebirge (Bulgarien). Zeitschrift für Gletscherkunde und Glazialmorphologie 39: 99-114

Hughes PD. 2007. Recent behaviour of the Debeli Namet glacier, Durmitor, Montenegro. Earth Surface Processes and Landforms 32: 1593-1602.

Hughes PD. 2008. Response of a Montenegro glacier to extreme summer heatwaves in 2003 and 2007. Geografiska Annaler 90: 259-267.

Hughes PD.in press. 21st century glaciers and climate in the Prokletije Mountains, Albania. Arctic, Antarctic and Alpine Research. DOI: 10.1657/1938-4246-41.4.

Hughes PD, Woodward JC, Gibbard PL. 2006. The last glaciers of Greece. Zeitschrift für Geomorphologie 50: 37-61.

Hughes PD, Gibbard PL, Woodward JC. 2007. Geological controls on Pleistocene glaciation and cirque form in Greece. Geomorphology 88: 242-253.

Hughes PD, Woodward JC. 2008. Timing of glaciation in the Mediterranean mountains during the last cold stage. Journal of Quaternary Science 23: 575-588.

Hughes PD, Woodward JC. 2009. Glacial and periglacial environments. In The Physical Geography of the Mediterranean Basin, Woodward JC. (ed). Oxford University Press: Oxford; 353-383.

Ivy-Ochs S, Kerschner H, Maisch M, Christl M, Kubik PW, Schlüchter C. 2009. Latest Pleistocene and Holocene glacier variations in the European Alps. Quaternary Science Reviews. 28: 2137-2149 doi:10.1016/j.quascirev.2009.03.009

Katsoulis BD, Kambetzidis HD. 1989. Analysis of the long-term precipitation series at Athens, Greece. Climatic Change 14: 263-290.
Kern Z, Surányi G, Molnár M, Nagy B, Balogh D. 2007. Investigation of natural perennial ice deposits of Durmitor mts, Montenegro. Proceedings of the 2nd International Workshop on Ice Caves, Demänská Dolina, Slovak Republic, 8-12 May 2006.

Marović M, Marković M. 1972. Glacial morphology of the Durmitor Mt. wider area (in Serbian). Geoloski anali Balkanskog poluostrva XXXVII: $37-48$.

Matthews JA. 2005. 'Little Ice Age' glacier variations in Jotunheim, southern Norway: a study in regionally controlled lichenometric dating of recessional moraines with implications for climate and lichen growth rates. The Holocene 15: 1-19.

Matthews JA, Briffa KR. 2005. The 'Little Ice Age': re-evaluation of an evolving concept. Geografiska Annaler 87: 17-36.

McGregor GR, Gellatly AF, Bücher A, Grove JM. 1995. Climate and glacier response in the Pyrénées, 1874-1994. Zeitschrift für Gletscherkunde und Glazialgeologie 31: 207-214.

Meier MF, Dyurgerov MB, McCabe GJ. 2003. The health of glaciers: recent changes in glacier regime. Climatic Change 59: 123-135.

Meierding TC. 1982. Late Pleistocene glacial equilibrium-line in the the Colorado Front Range: a comparison of methods. Quaternary Research 18: 289-310.

Messerli B. 1967. Die eiszeitliche und die gegenwartige Vertgletscherung im Mittelemeeraum. Geographica Helvetica 22: 105228.

Milivojević M, Menković L, Ćalić J. 2008. Pleistocene glacial relief of the central part of Mt.Prokletije (Albanian Alps). Quaternary International 190: 112-122.

Mortara G, Baroni C, Meneghel M. 2008. Fluctuations of the Italian glaciers 2007. Geografia Fisica e Dinamica Quaternaria 31: 255-313.

Nesje A, Dahl SO. 2000. Glaciers and Environmental Change: Key Issues in Environmental Change Series. Arnold.

Pecci MD, Agata C, Smiraglia C. 2008. Ghiacciao del Calderone (Appenines, Italy): the mass bilance of a shrinking Mediterranean glacier. Geografia Fisica e Dinamica Quaternaria 31: 55-62.

Repapis CC, Philandras CM. 1988. A note on the air temperature trends of the last 100 years as evidenced in the Eastern Mediterranean time series. Theoretical and Applied Climatology 39: 9397.

Sifrer M. 1963. New findings about the glaciation of Triglav. Geografski zbornik 8: 157-210.

Sissons JB, Sutherland DG. 1976. Climatic inferences from former glaciers in the south-east Grampian Highlands, Scotland. Journal of Glaciology 17: 325-346.

Smith GW, Nance RD, Genes AN. 1997. Quaternary glacial history of Mount Olympus, Greece. Geological Society of America Bulletin 109: 809-824.

Triglav-Čekada M. 2007. Photogrammetrical monitoring of the Triglav glacier in Slovenia. In Proceedings of 5th Mountain Cartography Workshop, Bohinj, Slovenia, 29 March -1 April 2006, Petrovič D (ed). Zürich, International Cartographic Association, Commission on Mountain Cartography; Ljubljana: Association of Surveyors of Slovenia, Section of Cartography, Faculty of Civil and Geodetic Engineering; 242-248.

Vasiljević D. 1997. Sadrzaj metala i radioktivnost leda sa ostataka lednika Debeli namet na Durmitoru. Zbornik radova: Rizik tehnoloskih sistema i zivotna sredina, Nis; 145-148.

Villa F, Tamburini A, Deamicis M, Sironi S, Maggi V, Rossi GC. 2008. Volume decrease of Rutor Glacier (Western Italian Alps) since Little Ice Age: a quantitative approach combining GPR, GPS and cartography. Geografia Fisica e Dinamica Quaternaria 31: 63-70. 